\title{
WILDERNESS ESSAY
}

\section{The Great Earthquake in Nepal-A Personal View}

\section{The Earthquake}

At about noon local time on April 25, 2015, a major (magnitude 7.8) earthquake shook much of Nepal and parts of India and Tibet. The earthquake killed more than 8000 people and injured tens of thousands more. Hundreds of thousands of homes and other buildings were damaged or destroyed. Further deaths, injuries, and damage occurred the next day because of a magnitude 6.7 aftershock and again on May 12 with a magnitude 7.3 aftershock.

When the earthquake struck, I was serving as faculty for a continuing medical education trek in the Khumbu (Mt Everest) region of Nepal. The group was en route to Everest Base Camp. We were having lunch in a teahouse in Somare, a small village between 2 larger villages, Pangboche and Dingboche. It was windy and snowing. Without warning, the entire room started to shake violently. We quickly realized that this was a very large earthquake. Everyone in the group walked outdoors through a door that led directly to a courtyard. Once in the courtyard, we had some difficulty standing up during the violent shaking, but we were in no danger from rocks that might fall from the 1-story building on 2 sides of the courtyard. As the earthquake subsided, a boulder rolled out of the clouds from Tawoche Peak (6542 m [21,463 feet]) directly above us. Fortunately, we were not in the path of the boulder. We watched as it stopped just short of the village.

All local communications had been disrupted. The group was supposed to be carrying a satellite phone, which had been left in Kathmandu. The Khumbu usually has good cell phone coverage. The satellite phone had never been used in years of similar treks.

After finishing lunch in the undamaged teahouse, we continued to walk to the village of Dingboche, our destination for the night. We crossed 2 small landslides on the way. Our lodge, like most buildings in Dingboche, was not damaged. It was, reassuringly, a woodframe building. Other than the lack of communications, things seemed relatively normal. We were unaware of events beyond our immediate surroundings.

The next morning I walked over the ridge to Pheriche to visit the Himalayan Rescue Association (HRA) Aid Post. As the Associate Medical Director of the HRA, I had assigned the doctors working there. When I reached the top of the ridge, I could see that many buildings in Pheriche had been damaged by the earthquake (Figure 1). There was a crowd of people on the main trail near the aid post and helicopters landing just below the trail, in the riverbed (Figure 2).

\section{Aftermath of the Avalanche at Everest Base Camp}

When I reached the aid post, I found it occupied by many patients who had been seriously injured by an avalanche at Everest Base Camp. The patients occupied all the available beds and floor space in the aid post as well as all the floor space in the large detached sunroom in front. Additional patients were on the floor and in chairs at Panorama Lodge next door. By the time I arrived, helicopters had dropped off all the casualties from the base camp. The same helicopters were about to start reloading them to be flown to the airport in Lukla for treatment in the small hospital there or for further transfer to Kathmandu.

Two of the doctors were evaluating and treating patients. The third doctor was at the landing zone, prioritizing patients for further transport (Figure 3). A nonmedical volunteer and our senior health assistant were supervising the loading of patients into helicopters.

The first problem I encountered was that there were many patients in the clinic who would need to be carried to the helicopter staging area. I asked our nonmedical

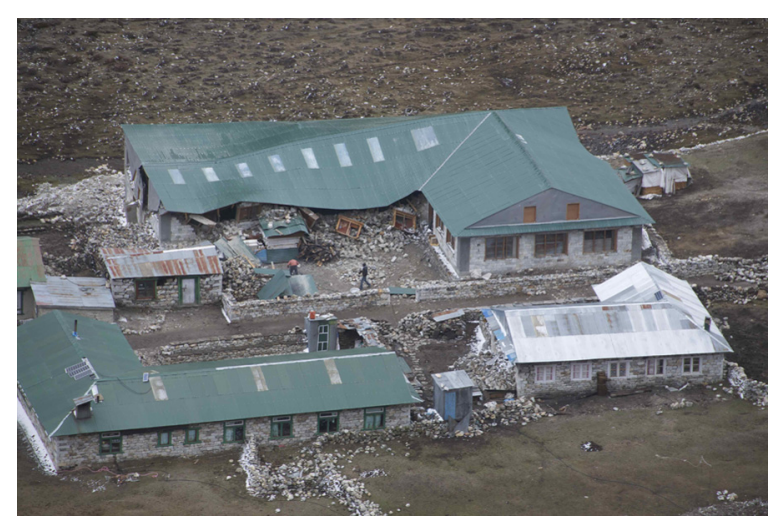

Figure 1. Damaged lodges in Pheriche on the day after the earthquake, April 26, 2015. 


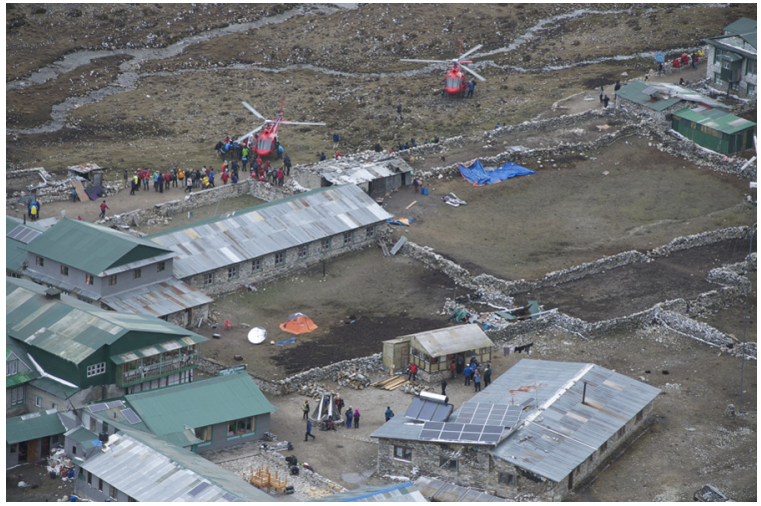

Figure 2. Mass casualty incident at Pheriche, April 26, 2015.

volunteer to tell the people in the large crowd to go to the clinic and bring patients to the staging area. The second problem was that we had run out of stretchers. I told the people who came to the clinic that they shouldn't wait for stretchers but should carry patients on mattresses. This was quite easy, as all of the patients were already on mattresses. Everyone, patients and carriers, ended up where they needed to be next to the landing zone.

During the next few hours, all patients were placed on helicopters, which flew to Lukla (Figure 4). One doctor served as gatekeeper, making sure that the most seriously injured patients were placed on helicopters before less seriously injured patients. Once the stretcher patients were loaded, we brought the walking wounded to the staging area, where they sat on chairs awaiting transport. The process went quickly. Several smaller helicopters and 1 large one, an MI-17 (Figure 5), whisked away the patients.

We finished the mass casualty evacuation after noon and returned to the aid post. We were standing outdoors in front of the building when the first large aftershock (magnitude 6.7) hit. This aftershock was not as severe as

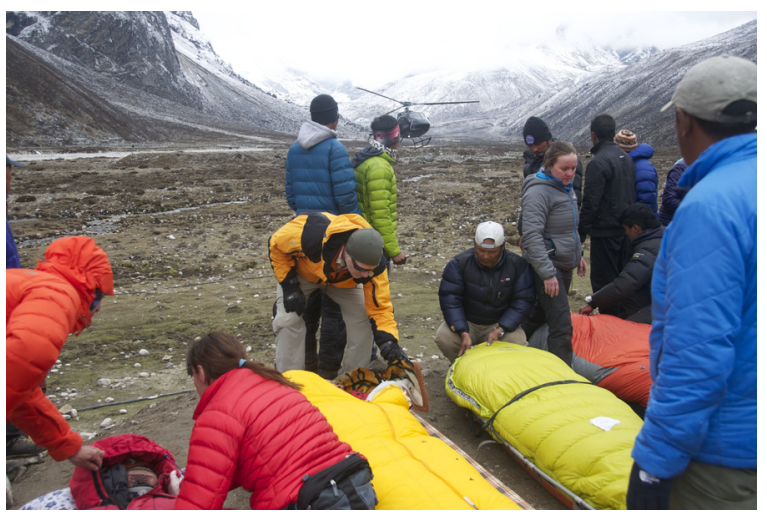

Figure 3. Casualties awaiting transport at Pheriche, April 26, 2015.

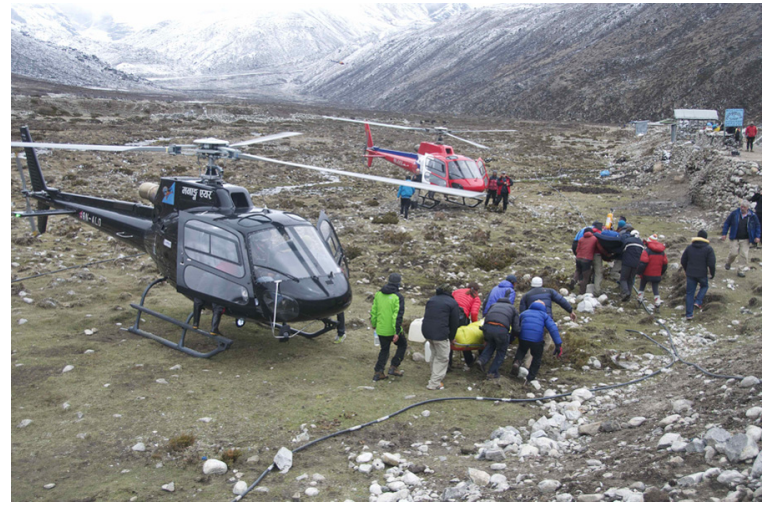

Figure 4. Loading casualties onto helicopters at Pheriche, April $26,2015$.

the original quake, but seemed to last longer. There had been many significant aftershocks on the day of the quake and were to be more in subsequent days and weeks.

\section{The Rest of the Trek}

The next day I returned with my group. We witnessed helicopters bringing down the bodies of those who died at Everest Base Camp. It was clear that we wouldn't be going to Everest Base Camp or even to Lobuje, the last village of any size on the way to the base camp. We had heard that Kathmandu had sustained heavy damage and that most restaurants and shops were closed. Meanwhile, we were comfortable and safe where we were. We weren't sure whether some of the lodges on our return route were intact. Because local telephone communications had not yet been restored, we started a leisurely descent the next day, sending runners ahead to check on conditions.

There was minor damage to the trail and major damage to some buildings. All the lodges where we

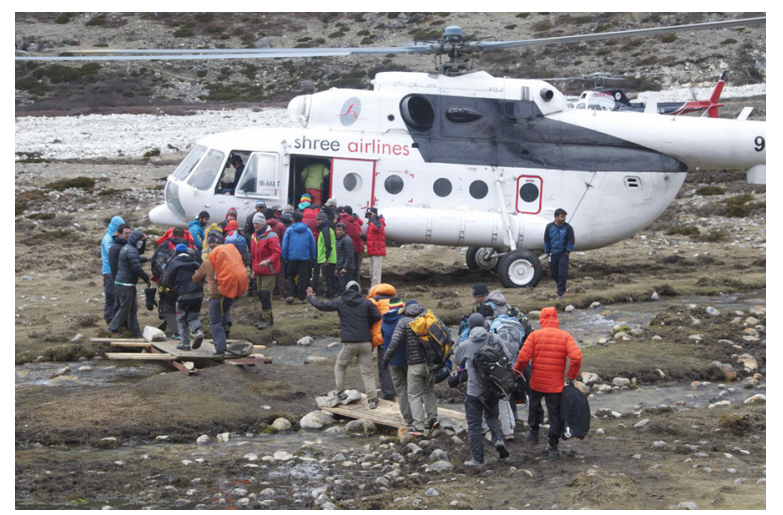

Figure 5. Loading casualties onto MI-17 helicopter at Pheriche, April $26,2015$. 


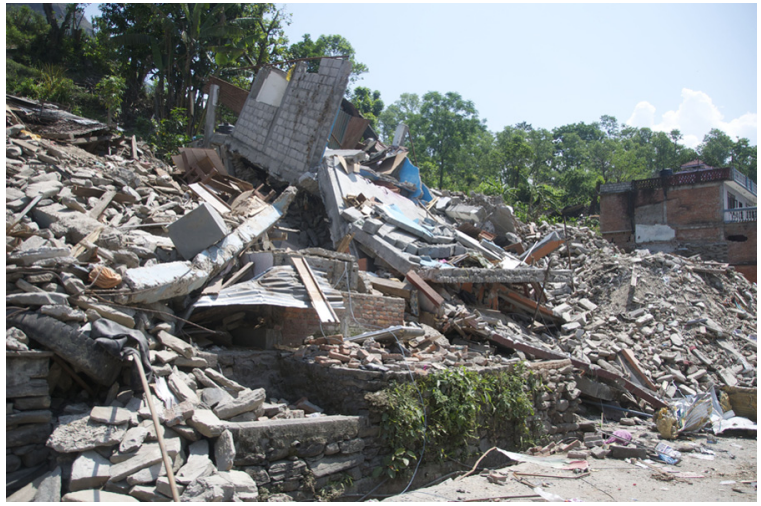

Figure 6. Destroyed buildings near Dolaghat, May 6, 2015.

planned to stay were safe. One had minor damage. Some villages were mostly intact, while others were devastated. Some buildings will be a total loss, while others can be repaired. The HRA Aid Post was already being repaired on the day after the earthquake. The only damage to the building was the collapse of a small part of an exterior non-load-bearing stone wall. The repair survived the subsequent large aftershock of May 12 with no damage. It will take months to repair the buildings that can be repaired and several years to rebuild the buildings that were destroyed. In spite of the damage, there had been no fatalities and few injuries. There was no need to provide medical care as we trekked to the airport at Lukla.

\section{Postearthquake Kathmandu}

When we returned to Kathmandu, we found a city with little apparent damage other than collapsed buildings at numerous holy sites. Road damage was being repaired. Most shops and restaurants were open.

I had worried for 25 years about the effects of the inevitable large earthquake on buildings in Kathmandu. Many high-rise buildings had been built in the last few years. A relatively small number of buildings collapsed, but most of the high rises were intact. Most of the buildings that collapsed were illegally built with extra floors above the number for which they had been approved. A few of the high rises have been condemned. Some will need repairs. The majority are sound. A few months later, people are moving back into them.

\section{Needs Assessment in the Sindhupalchok District}

The evening I returned to Kathmandu, I began planning the next steps with the HRA. The doctors at the HRA Aid Post in Manang, on the Annapurna Circuit, where there was little damage, decided to close the aid post early and returned to Kathmandu. Very few trekkers were passing through Manang. They thought they could be more useful by joining the earthquake relief effort. A few days later, I helped the HRA organize a trip to an area with widespread damage from the earthquake.

I led the team, which consisted of one of the Manang doctors, another doctor who had been trekking and had been at Manang during the earthquake, and a third doctor, originally from Nepal, who had flown from his home in the United States to help with earthquake relief. We were supported by a very experienced health assistant from the HRA. The other 2 doctors who had been at Manang stayed in Kathmandu to arrange a helicopter delivery of tents to 2 remote villages.

The Nepal Ministry of Health and Population in conjunction with the World Health Organization asked the HRA to do a needs assessment in 4 villages in the Sindhupalchok District, one of the hardest hit areas. We took medical equipment and supplies in case we encountered patients who needed medical care, but our mission was to perform a survey to help guide postearthquake relief efforts. We did not intend to see patients in clinics. We knew that almost all victims of the earthquake who were seriously injured had either died as a result of their injuries or been evacuated to Kathmandu for definitive care in the first few days after the quake.

We set out early in the morning for the several-hour drive. As we approached the Sindhupalchok District, we saw many houses and larger buildings that had been damaged or destroyed (Figure 6). The farther we went, the more damage we saw. Many buildings had been reduced to rubble. We began to see large cracks in the dirt road that led to our villages.

Late in the morning, before reaching Chokarte, our first assigned village, we stopped at the Dumthang Health Post where the trekking agency that arranged our trip, not understanding our mission, had arranged a clinic for us. The health post was a well-constructed concrete building and was undamaged. Even in areas with heavy damage, concrete buildings with reinforced (rebar) construction sustained little or no damage. About 40 patients were waiting for us at the clinic. All had to be seen. Almost all the patients were presenting with chronic conditions or for acute minor illnesses or injuries unrelated to the earthquake. A few patients had injuries from the earthquake, mostly from tripping and falling while running to safety. All these patients were healing well and required only reassurance. We formed 2 teams. An emergency physician and an internist worked with our very experienced health assistant as the interpreter. As the other emergency physician I worked with our Nepali doctor, a transplant nephrologist, who needed no 


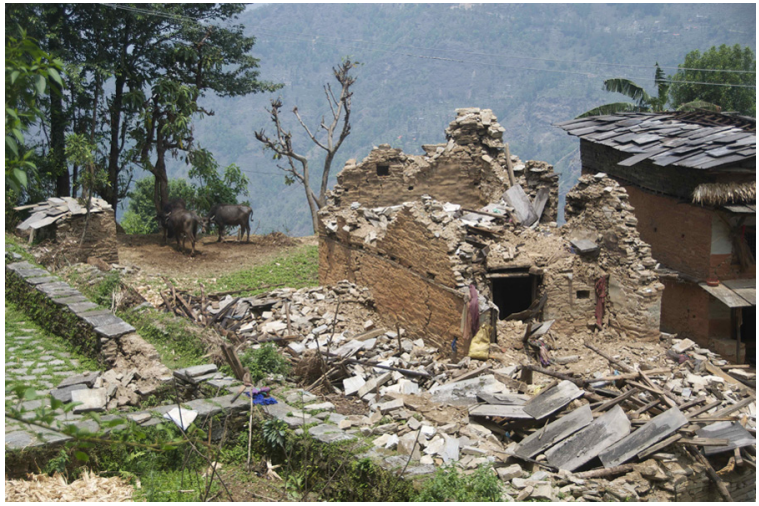

Figure 7. Destroyed farmhouse, Chokarte, May 7, 2015.

interpreter. He was very enthusiastic. He did well with a little coaching in general medicine and orthopedics.

While we were seeing patients, a group from Nepal Medical College arrived on their way back to Kathmandu after holding a multiday clinic in Piskar, the second village we planned to visit. There was clearly no point in our visiting Piskar, as this group had already surveyed the needs there.

After we had seen all the morning patients we drove to a small building about 20 minutes away. There we saw another 40 or so patients who had been waiting since morning. We were impressed at both clinics with the large number of elderly patients, many in their 80 s and $90 \mathrm{~s}$, as well as the number of mothers with young children. As in most of Nepal, many young men were abroad, primarily working in the Middle East, because of the lack of local jobs.

After a late dinner and a restful night in tents in a field, we continued to Chokarte, where we met with the Village Development Council. In Chokarte, there had been 126 houses of which only 1 was still habitable. The others were severely damaged or destroyed (Figure 7). All the people who had been injured in the quake had been evacuated to Kathmandu by helicopter. Nobody was killed in Chokarte during the quake because most people had been working in the fields.

The main needs in Chokarte, as in every village in the hardest hit districts of Sindhupalchok, Rasuwa, Gorkha, and Dhading, were shelter and sanitation. The healthcare system was largely intact. Most people were living under tarps. After the earthquake, all of the villagers had been sleeping under a large tarp and cooking together. Some people had moved back to the vicinity of their homes for sleeping and cooking to work in the fields. Before the earthquake, every home had had a toilet. All the toilets had been destroyed, and only a few had been rebuilt. Many people had no alternative but to defecate in the open. They knew to wash their hands and had enough water. Water was flowing better after the quake than before.

People had received sacks of rice from the government. Food shortages were anticipated in the absence of further aid because some food supplies had been ruined or at least made inaccessible by the collapse of houses. A large number of domestic animals were also killed by the earthquake. In addition, many cultivated terraces had developed cracks in the earthquake and were considered too unstable for planting. The terrain in and around Chokarte is very steep, as in most of the areas affected by the earthquake. Once the monsoon arrived, there would likely be landslides that could cause injury or death and that might make the few local roads impassible.

As we were concluding our discussion with the Village Development Council, a Nepal Army officer arrived and invited us to a small camp near the village temple, just up the hill from where we were standing. His 4-man team had been in the village for 4 days, providing aid and seeing patients. All of our villages had been assessed by the army. Army teams were also in 2 of our other villages, Ghortale and Kharkali. About $90 \%$ of the army was deployed to villages in the affected areas to provide postearthquake assistance. It seemed most prudent to return to Kathmandu so that the doctors could be sent out to other areas that might have greater medical needs.

Foreign doctors were not needed to provide disaster relief in most of the areas affected by the earthquake. Having foreign doctors see patients in functioning clinics in Nepal has the negative effect of undermining the confidence of local people in the healthcare system. On the other hand, foreign aid in the form of shelter and reconstruction are sorely needed. These jobs are not for doctors but for engineers, builders, and sanitation experts.

\section{Rebuilding Nepal}

In addition to the mass destruction of housing and businesses, many schools were destroyed. Clinics generally fared better, although many health aides who staff the clinics lost their houses. Some have left the villages to stay with relatives in less-damaged areas, leaving holes in the health system.

Nepal is an impoverished and politically fragmented country, but the earthquake gave people the opportunity to work together. The government was not well prepared for a disaster and made some missteps. In many cases people stepped up to help themselves and their neighbors by providing food and clothing to those who lost 
everything in the quake and by starting to rebuild without waiting for government assistance. Foreign aid poured in, both money and workers, but hardly enough for the scale of the disaster.

In many areas, the ability to deliver aid is severely constrained by the lack of infrastructure. Roads were in poor shape before the quake damaged them further. Many places were already beyond the reach of roads. It will take years to rebuild. People have realized that new buildings will need to be better constructed than the ones they replace. There are huge challenges, but it is encouraging that there are many willing hands to do the necessary work. The national mood has had a note of optimism in spite of the terrible losses and hardships many people have endured.

\section{Return Home}

I had planned to spend the rest of May filling in for one of the doctors in Manang who needed to leave before the end of the season. Afterward, I was going to assess the living conditions and health needs of a group of vulnerable fungus collectors above Manang. That project will have to wait until next year. I returned home to Alaska with a heavy heart.

\section{Return to Nepal}

I returned to Nepal in August 2015, as scheduled, to help teach a mountain rescue course for Nepali doctors and mountain guides and to help staff the HRA annual temporary clinic caring for pilgrims in Gosainkunda in the Rasuwa District, one of the hardest hit areas. Langtang village, near Gosainkunda, was destroyed in an avalanche and landslide in the first earthquake. Several hundred people were killed in this disaster. The government has reopened the trails in the Langtang area and has rerouted the trail to Gosainkund Lake to avoid a small landslide on the old trail. There were fewer landslides than predicted in earthquake-damaged areas.

There have been no food shortages, no large disease outbreaks, and no civil unrest as a result of the earthquakes. Landslides are reported to be more common in earthquake-affected areas, but landslides have also occurred in other parts of the country as they do every year during the monsoon. Some buildings have been rebuilt, while many more have yet to be reconstructed. Many people are living in temporary shelters that are better than tarps, but are not as comfortable as houses. A large amount of monetary aid has come from expatriate Nepalis. There is no need for foreign healthcare providers except in projects that were ongoing before the earthquakes occurred.

\section{Outlook for Nepal}

The Great Earthquake of 2015 was a watershed event for Nepal, one of the least-developed countries in the world. All branches of the government realize that their responses to the earthquake could have been better. They are actively working to make sure that they will react more quickly and effectively in a future disaster. One of the bright spots was the role of the army, which rapidly mobilized to provide aid in the affected areas. The scope of necessary reconstruction is huge and will take years to complete. Progress is being made, but as of September 2015, the government had not yet established a planned national reconstruction authority.

The people of Nepal have learned how to pull together toward a common goal. Although there are still many political schisms, the earthquake was a key event to break the logjam blocking the adoption of a new constitution. There are many problems that stand in the way of a bright future for Nepal, but now there is the political will to work on solving these problems.

\section{Acknowledgments}

The team would like to thank the Drozd Foundation for financial support for the survey, Chairman D.B. Koirala and Chomolhari Trekking for arranging the trip to Sindhupalchok, and the HRA staff in Kathmandu, especially the Executive Director, Prakash Adhikari, for logistical support. Dr Zafren was supported by the Himalayan Rescue Association of Nepal.

Ken Zafren, MD

Department of Emergency Medicine, Stanford University Medical Center, Stanford, CA; Department of Emergency Medicine, Alaska Native Medical Center, Anchorage, AK; Himalayan Rescue Association, Kathmandu, Nepal E-mail address: kenzafren@gmail.com 